\title{
Anthrovision
}

Vaneasa Online Journal

$4.2 \mid 2016$

Imagination/Ineffability

\section{Images of Ecstasy and Affliction}

The Camera as Instrument for Researching and Reproducing Choreographies of Deviance in a Southern Italian Spider Possession Cult

\section{Michaela Schäuble}

\section{(2) OpenEdition}

1 Journals

\section{Electronic version}

URL: http://journals.openedition.org/anthrovision/2409

DOI: 10.4000/anthrovision.2409

ISSN: 2198-6754

\section{Publisher}

VANEASA - Visual Anthropology Network of European Association of Social Anthropologists

\section{Electronic reference}

Michaela Schäuble, «Images of Ecstasy and Affliction », Anthrovision [Online], 4.2 | 2016, Online since 31 December 2016, connection on 30 April 2019. URL : http://journals.openedition.org/ anthrovision/2409; DOI : 10.4000/anthrovision.2409

This text was automatically generated on 30 April 2019.

(c) Anthrovision 


\section{Images of Ecstasy and Affliction}

The Camera as Instrument for Researching and Reproducing Choreographies of Deviance in a Southern Italian Spider Possession Cult

\section{Michaela Schäuble}

1 "This symbol [of the taranta] offers a perspective for imagining, hearing and watching what we lack imagination for and are deaf and blind to, and which nevertheless peremptorily asks to be imagined, heard and seen."

2 (Ernesto De Martino, The Land of Remorse 2005 [1961]: 36) ${ }^{1}$

\section{"Afflictions of the Imagination"}

In the 1950s the Italian philosopher, anthropologist and historian of religion Ernesto de Martino (1908-1965) undertook his famous journeys to the south of Italy, mainly the regions of Apulia and the Basilicata. ${ }^{2}$ He studied Lucanian funeral rituals and tarantism, a rural possession cult that is believed to cause a nervous disorder through the (imaginary) bite of the tarantula spider and is cured through music and trance-dancing by the afflicted women. Although De Martino himself never filmed and could not take photographs, his writings inspired a whole generation of Italian filmmakers as well as photo- and phonographers to explore magic practices and ritual exorcism exercised through dance and music in their native Italy. Documentarians such as Gianfranco Mingozzi (1932-2009), Diego Carpitella (1924-1990), Cecilia Mangini (*1927), Vittoria de Seta (1923-2011), Michele Gandin (1914-1994) and Luigi di Gianni (*1926) captured innumerable photographs, films, and sound recordings of religious ecstasy, states of possession and trance, and exalted ritual lament. Today, these recordings are often acclaimed as the founding classics of Italian audiovisual anthropology, yet they were not produced in a vacuum.

In the following, I will shed some light on the significance of the historical ethnographic context within which photographic and filmed images of seemingly possessed women were produced; in doing so I am less concerned with the photographic/filmic image as a document, but rather as a tool and catalyst for the exploration of reality. Starting with 
the assumptions that states of ecstasy and lamentations for the dead both share performative as well as mimetic qualities, and secondly, that the visual representation of these states are (almost) always achieved through artificial evocation and reconstruction, I argue, that the affected 'acting' persons actively wish to be seen. Trance possession, and ecstatic states do not occur without audiences, which make them ideal situations in which to examine audiovisual recording and research techniques, as well as to experiment with staging and reconstruction in collaboration with those in front of the lens.

5 As in all cases of "imaginary afflictions" (imaginariae), which have physical and psychological symptoms but no identifiable biological causes, rational explanation is sought in the visual, or visible: that which can be seen and photographically captured or represented. ${ }^{3}$ Not unlike the photographers and filmmakers with whom he worked, De Martino was obsessed with the realist dream that scientifically inexplicable 'other', 'deviant' internal states could be made accessible and comprehensible via their visible symptoms and manifestations; he sought for an ontological representation of visible bodies and symptoms, whereby the felt and embodied experiences of the afflicted themselves naturally remained invisible.

6 I propose that the images of ecstasy and affliction of Apulian tarantati (mainly "tarantuled" women and a few men) produced in the context of De Martino's expeditions were actually strongly inspired by the scientific and medical photography of the nineteenth and early twentieth centuries. It is by no means my intention to pathologize tarantism or other religiously-induced phenomena, or to liken them with outmoded medical diagnoses such as hysteria or dancing mania. Early photographs of hysterics and the mentally ill were taken in order to capture and illustrate deviance. The same cannot be said of the images of religious ecstasy and trance states produced in Southern Italy even though in both cases real crises, personal or social, were believed to be what provoked the exalted states that were publicly performed. Nonetheless, considering the role that visual media played in the study and categorization of hysteria and mental illness can bring a fruitful perspective from which to examine De Martino's use of film and photography, his approach to research, and his understanding of audiovisual media.

7 Ethnographic depictions of the phenomenon of Apulian tarantism draw on turn-of-thecentury scientific paradigms (i.e. experimental use of photography to detect choreographic patterns of ecstatic episodes) and also link visual manifestations of mental illness to religious imagery. It is the spectacular visibility of somatic expressions that make both $19^{\text {th }}$-century concepts of hysteria and Apulian tarantism "theatrical illnesses" (Hustvedt 2011). While not contending that the tarantuled women (tarantate) in Apulia have directly drawn on the existing visual lexicon of hysterical postures, this article explores and compares (mainly photographic) representations of expressive contractures and poses of the convulsive female body, arguing that $19^{\text {th }}$-century physicians and $20^{\text {th }}$ century anthropologists alike used (audio-)visual media to register and "preserve the durable trace of [...] pathological manifestations" (Londe 1893: 64) with the aim of creating a repertory of characteristic images of ecstasy and affliction. 


\section{Audio-Visual Recordings and Reenactments in Ernesto de Martino's 1950s expeditions to Southern Italy}

Although he himself drew attention to similarities between tarantism and hysterical symptoms, De Martino always maintained that tarantism should not be demoted to an illness (De Martino 2005 [1961]: 22); instead the phenomenon's cultural autonomy should be key to its analysis. First and foremost, he was determined to break down the static image of Apulian tarantism and to avoid its interpretation as a "relic" or "survival" and its "reduction to antecedents" (De Martino 2005 [1961]: 7; 177) by all means. Instead of looking for relics or traces of the past in tarantism and other forms of religious ecstasy, he compared it to similar contemporary phenomena (including, among others, Haitian Vodou), without neglecting the significance of tarantism's own specific historical background. His first goal, as I see it, was to counter the static nature of preceding representations and analyses and to outline a stylized choreography or codified catalogue of ecstatic gestures; and images - sketches, photographs, and moving images, i.e., film were to play a key role in his efforts to achieve this (see also Pisapia 2013a; 2013b).

9 De Martino's intentions for commissioning audio-visual recordings during his field research were manifold. First of all, he wanted to highlight the performative characteristics of ancient lamentations, ritual choreography, and ecstatic states. By evoking the sensory aspects of the movements, the body techniques, the cries, the mourning, he meant to make the "spectacle of the crisis" comprehensible and bring it to life. "When he set out on his first field trip to Lucania, he knew he was to encounter a world of shadows and charged atmospheres, and in order to catch its spirit it would be necessary to capture the sounds, the gestures, the feel of those places“, as Daniela Cascella writes (Cascella 2012). For De Martino, the images and recordings were also useful documents that he could keep hold of and also use to study the ecstatic and ritualized gestures and movements in more detail and/or slow motion. Last but not least, De Martino feared that the religious practices he was studying were being transformed or disappearing, and his endeavor to document them could also be seen as a form of salvage anthropology.

In the introduction to La terra del rimorso [The Land of Remorse: A Study of Southern Italian Tarantism, 1961] De Martino states that the initial idea of carrying out fieldwork on tarantism came to him when looking at photographs that French photographer André Martin had taken of 'possessed' women (and a few men) in the small town of Galatina in 1957. 

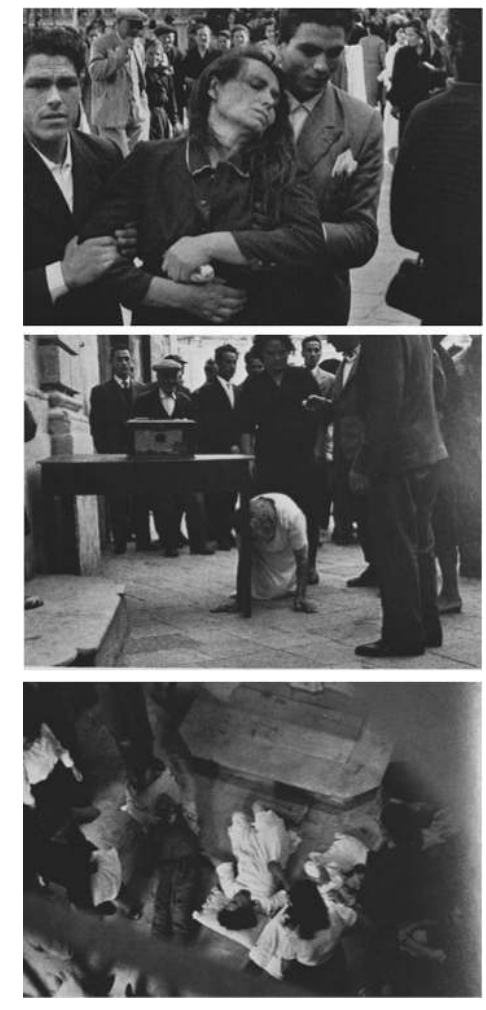

Photos by André Martin in 1957

He writes that the historiographic coherence of these photographic images constituted "a knot of extreme contradictions" (De Martino 2005 [1961]: 11) and calls them a stimulus for his method to study the religious history of the South through exemplary singular episodes. His interest in audio-visual media would also break down the incoherent isolation of Apulian tarantism to which it was relegated by "fieldwork and the analysis of historical literature" (De Martino 2005 [1961]: 177). Therefore, I argue that his main incentive was to dissolve the static in the representation and the analysis of tarantism as well as of ritual lamentation.

However, De Martino remained highly skeptical of the epistemological significance of images and did not trust that photographs could transport ethnographic knowledge by themselves. To him, photography was hence no analytical tool but a kind of 'auxiliary science' that he did not consider capable of generating data. Consequently, the collaboration between the ethnographer and the photographers, phonographers and filmmakers was not always an easy one. Like during earlier expeditions, the photographers in 1959 were meticulously instructed by him; they held regular team meetings and had detailed contracts that specified what exactly they had to research and take pictures of, and how (Signorelli and Panza 2011). ${ }^{4}$ Only later, when it transpired that the images were much more than just an illustration of De Martino's written work, the photographers were credited as individual authors. In the case of the cinematographers, the nature of the cooperation differed. And although De Martino is listed as scientific adviser in many documentary films, he was never personally present on a set during shooting and sometimes he did not even know that a film was being made in one of his research locations. ${ }^{5}$ 

enactments as effective ethnological research methods and he continually emphasized that reconstructed performances were scientifically as valuable as 'authentic' data. In Morte e pianto rituale nel mondo antico [Death and Ritual Lament in the Ancient World, 1958], for example, he writes that an "artificial lament" was as "dramatic and demonstrative" as a real one (De Martino 2000 [1958]: 377); and in I Lamenti funebri e l'esperienza arcaica della morte [Funeral laments and the archaic experience of death, 1954] he states "the lamenter undergoes a gradual self-suggestion and, after hesitating a few times, immerses herself so deeply in her role that she really cries, perhaps remembering her own dead loved ones" (De Martino 2002 [1954]: 69; see also Forgacs 2014: 148). ${ }^{6}$ For this reason, and in addition to classic ethnographic methods such as participant observation and interviews, De Martino also made use of reconstructions and re-enactments. Unlike other leading international anthropologists of his time he always understood that all 'authentic rituals' are performances - and that is the reason why he did not see it as falsification or distortion to ask his informants to stage certain poses, trances and dances for the purpose of the recordings. De Martino, with reference to medical literature on tarantism, also referred to tarantella as "women's little carnival", thus highlighting the performative and mimetic aspects of the phenomenon (De Martino 2005 [1961]: 112; 128). In fact, staged situations suited his purposes better, because they pointed towards the constructed nature of 'authentic' episodes and because they allowed him to focus more clearly upon relevant details and motion sequences.

For him, magic and ecstatic ritual practices were manifestations of historicized cultural patterns that helped subalterns to deal with existential crises and to express their feeling of not belonging to the contemporary world, a state that De Martino referred to as loss of or crisis of presence," crisi della presenza” (De Martino 1947). It was within this conceptual framework that De Martino went about to study and expound Apulian tarantism as a culturally loaded and historically infused phenomenon; as part of a ritual therapy through dance, music and color symbolism - also referred to as a "musicalchoreutic-chromatic exorcism" - the afflicted persons (mainly women on the social margins) are commonly surrounded by a band of musicians playing drums and violins in an attempt to cure them. During these so-called "home therapies" (terapie domiciliari) they would publicly perform uncontrolled dances, scream and move in convulsive ways simulating possession by (and eventually the trampling on) a spider. During their wild, often obscene gestures these "tarantuled" persons (tarantati) would hold an imaginary dialogue with St. Paul, the patron saint against spider and snake bites. And on the feast of Sts. Peter and Paul, on June 29, they are traditionally brought to the St. Paul's chapel of Galatina to plea for grace and healing.

During their 1959 expedition, Ernesto De Martino, the photographer Franco Pinna and the ethnomusicologist Diego Carpitella pursued their intention to record and study motion sequences and 'choreographies' of ecstatic states, notably of tarantism (Signorelli and Panza 2011). They witnessed an 'authentic' home therapy in Nardò and visited the chapel in Galatina on the occasion of the feast-day of Saints Peter and Paul (De Martino 2005 [1961]). 


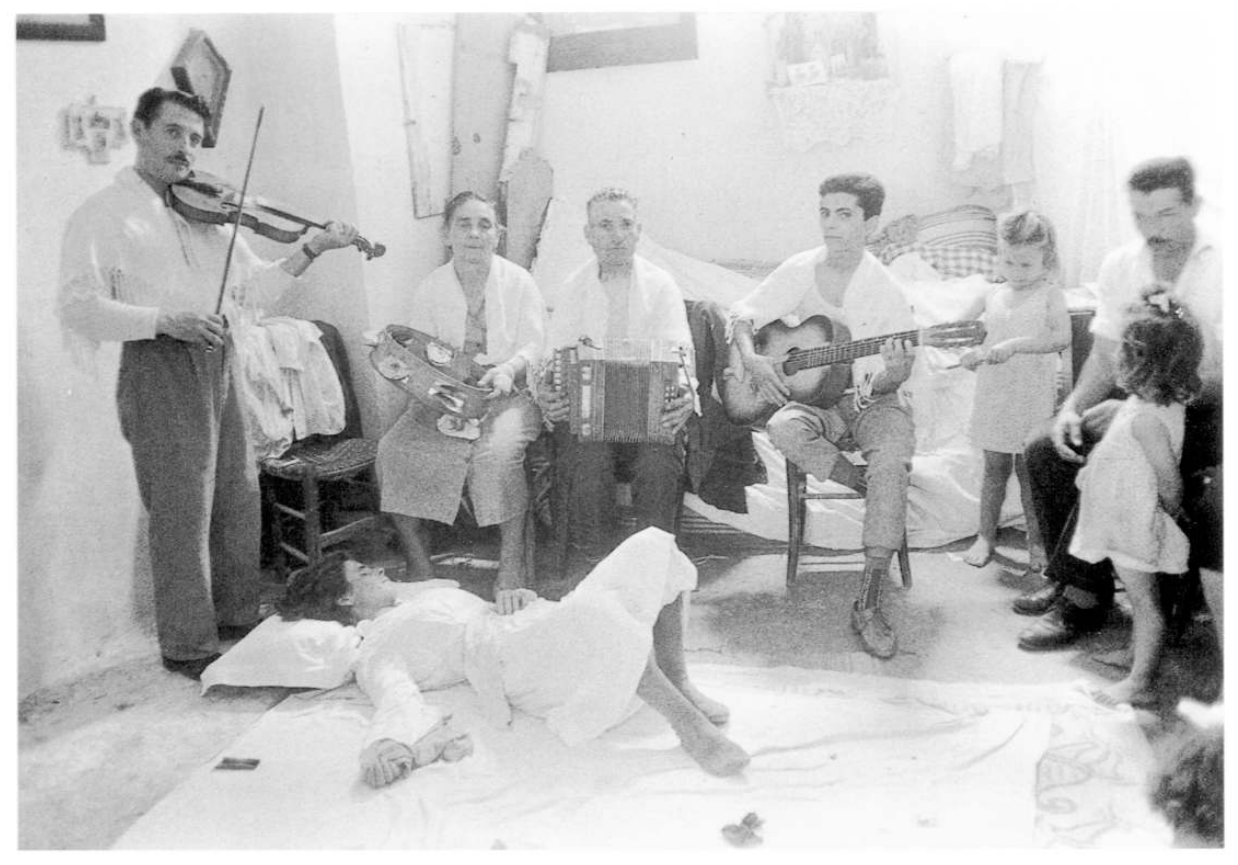

Photo by Franco Pinna in 1959

Between June $26^{\text {th }}$ and July $3^{\text {rd }} 1959$ Franco Pinna took over seventy photographs, some of which are reproduced in De Martino's monograph The Land of Remorse (2005: 135-174); the printed illustrations include the series "The choreutic cycle of Maria of Nardò" (fig. 1-20), "The choreutic cycle of Rosaria of Nardò" (fig. 21-26), "The symbolic reconstruction of the scene of the "first bite" (fig. 27-29), "Scenes in the Chapel and in the Street" (fig. 30-39), which are partly 'authentic' and partly based on reconstructions. The last series, Plate 46, which contains 15 photographs, is entitled "The choreutic modes of tarantism." To study the "choreutic modes" in more detail, de Martino, Pinna and Carpitella had constructed a setting in a hotel room where 'authentic' tarantati and mourners were asked to perform (and relive) their afflictions in a staged context (Pisapia 2013a). ${ }^{7}$ This photographic series, Reconstruction of tarantism (Raccolta 38 - Ricostruzione del tarantismo), pays "special attention to bodily motions and break down those movements analytically", as social anthropologist Jasmine Pisapia notes (Pisapia 2013a: 16). De Martino was particularly interested in documenting dance sequences and serial expressions of crises as he was convinced that by analyzing movement sequences he would be able to isolate formulistic gestures, from which he could then infer the dancers' inner states. Some of these photographs, however, were either never published or only printed much later (Gallini and Faeta 1999: 289-353) - in particular those which show the anthropologist at work and/or provide a self-referential look 'behind the scenes', exposing the reconstructed nature of the images. 

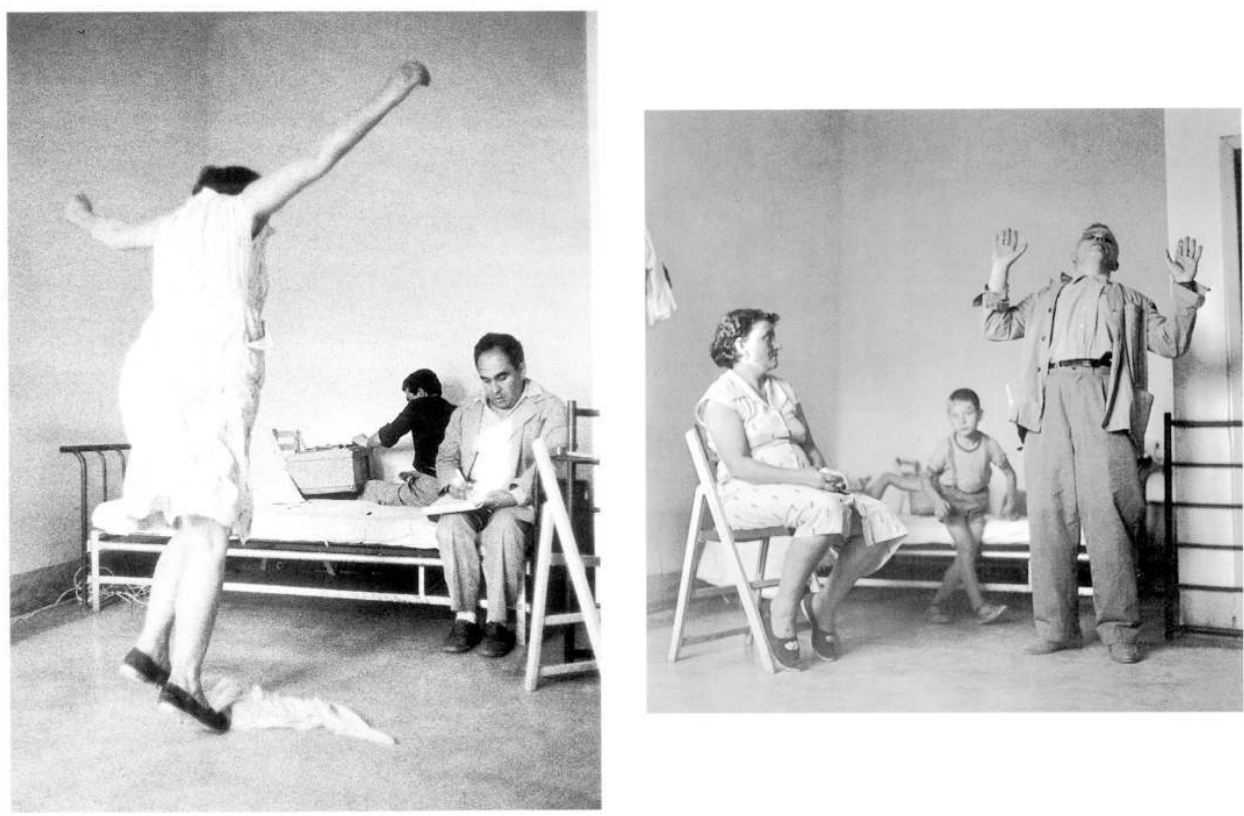

Accompanied by a technician of RAI (Radiotelevisione italiana), Carpitella recorded the sound, while De Martino took notes and mimicked or emulated the movements of some of the tarantate to better understand their choreographies.

Photos by Franco Pinna in 1959.

From the outset, the use of staged performances and reconstructions was a contested topic in De Martino's team. During a conversation in which De Martino's lifelong research assistant Clara Gallini and his fiancée and co-field-researcher Vittoria di Palma discussed the difficulties they encountered during the expeditions in Salento, Di Palma jokingly referred to the staged recordings as "uno spettacolo", ("a spectacle") (Gallini and Faeta 1999: 30). Clara Gallini, however, was skeptical about the experimental side of working in this way, and replied seriously: "But not everything can become a spectacle" ["Ma non tutto può diventare spettacolo"] (Gallini and Faeta 1999: 30).

\section{The "Absolute Eye" in 19th Century Medicine}

Interestingly, French philosopher and art historian Georges Didi-Huberman also takes the term "spectacle" as his starting point in his classic Invention de l'hystérie [Invention of Hysteria] in which he analyzes in detail photography's historical role in research on the phenomenon of hystero-epileptic fits (Didi-Huberman 2003 [1982]). Asking what the word "spectacle" might have meant in the expression "spectacle of pain" he traces the reciprocal relationship between photography and madness (Didi-Huberman 2003: 3).

From the mid-nineteenth century onwards, photography was used in the diagnosis and treatment of mental illness. A pioneer of this approach, the English psychiatrist and photographer Hugh W. Diamond, was convinced that he could cure his mainly female patients simply by showing them photographic images of themselves (Gilman 1993: 353; Regener 2000; 2010). ${ }^{8}$ In 1852 Diamond presented his photographs as part of a lecture 
entitled "Types of Insanity", and in 1856 he read a presentation on "The Application of Photography to the Physiognomic and Mental Phenomena of Insanity" before the Royal Society in London (Gilman 2014 [1976]: 17-24). Now held to be the earliest example of the systematic use of photography in clinical psychiatry, at the time the series of images facilitated the establishment of a typology of individual illnesses, such as "chronic mania", "suicidal melancholy", or "religious melancholy" (Gilman 2014 [1976]: 17-24). Already at that early stage, producing the images required staging and collaboration because even with the new wet plate process those photographed had to keep still for exposure times of several minutes. In some photographs Diamond added props such as peacock feathers, floral wreaths, or animals, which were supposed to symbolize the particular illness depicted.

Photographs of Patients
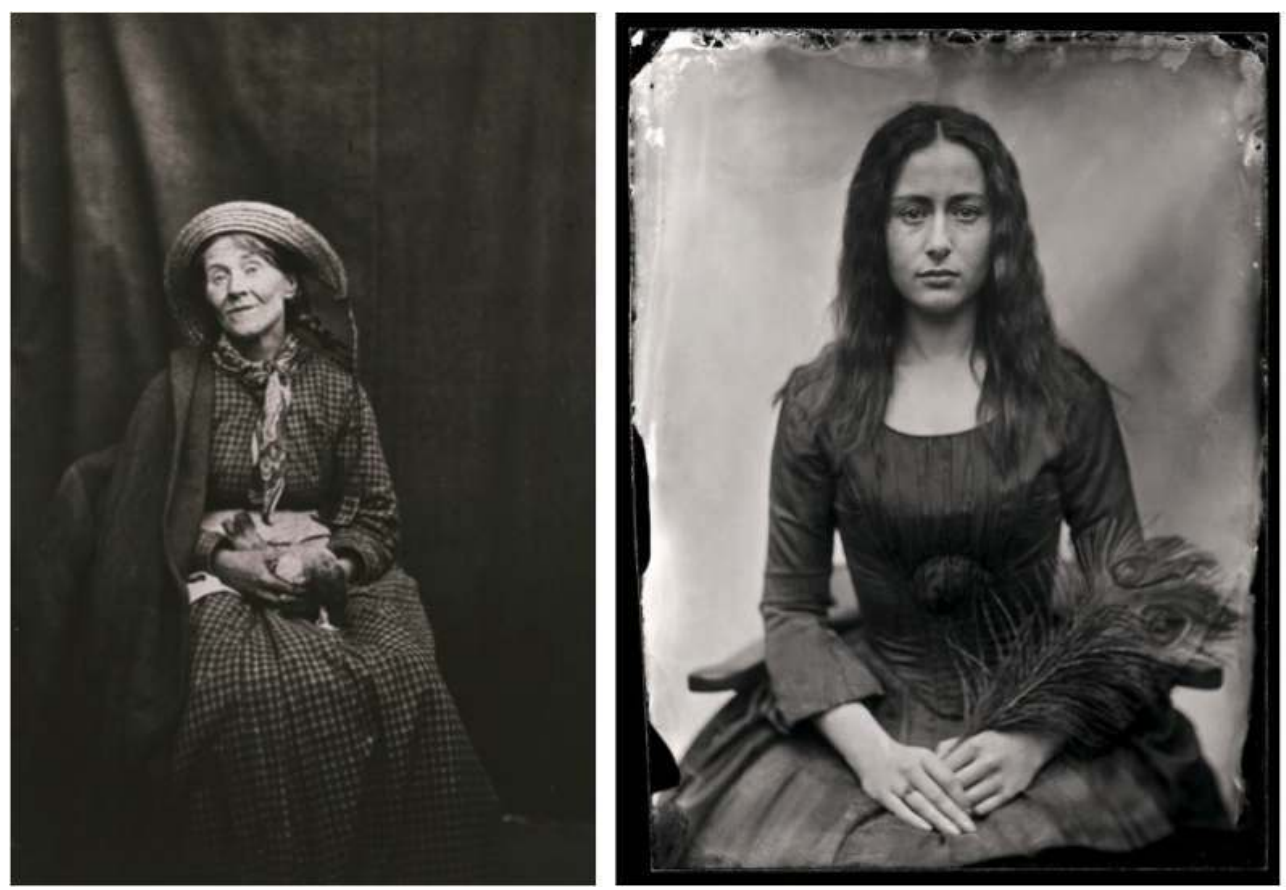

Surrey County Lunatic Asylum.

Photos by Hugh Welch Diamond. Albumen silver print from glass, about 1855.

The portraits were meant to illustrate illnesses, not ill women - all of whom were impoverished inmates of an asylum in southern England. The pictures made them objects of the scientific gaze. The representation of the patient becomes the product of a doctor's creative diagnosis, and the supposedly sick imagination of the patient is confronted by a real image, to which healing powers are attributed.

The camera also became a key instrument in research on hysteria. In his description of the Salpêtrière, the Parisian psychiatric institution where neurologist Jean-Martin Charcot established the clinical definition of 'hysteria', Didi-Huberman also refers to the institution as Charcot's "photographic clinic" (Didi-Hubermann 2003 [1982]: 283). ${ }^{9}$ Photography and vision were integral to the positivist scientific search for truth at that time, as is also demonstrated in Pasteur's need for the microscope to prove the existence of the microorganisms it made visible. 
Under Charcot, the Salpêtrière maintained its own photography department, which was led by chrono- and x-ray-photographer Albert Londe. Londe's task was to record manifestations of the illness known as 'hysteria' and to document and classify its visible effects upon patients' postures, gestures, facial expressions, actions, and physiognomy (Londe 1893; see also Gilman 1993: 352; Didi-Huberman 2003: 44ff). By 1882 Albert Londe had developed a system by which patients' physical, or more specifically, muscular, movements could be recorded, even during epileptic or 'hysterical' fits. He achieved this by using a camera with nine lenses, each linked to electromagnetically operated shutters that were released one after another with the aid of a metronome. The chronophotographic instrument was able to take individual shots at intervals ranging from a tenth of a second to several seconds.

\section{Photographic series of a patient diagnosed with 'hysteria'}

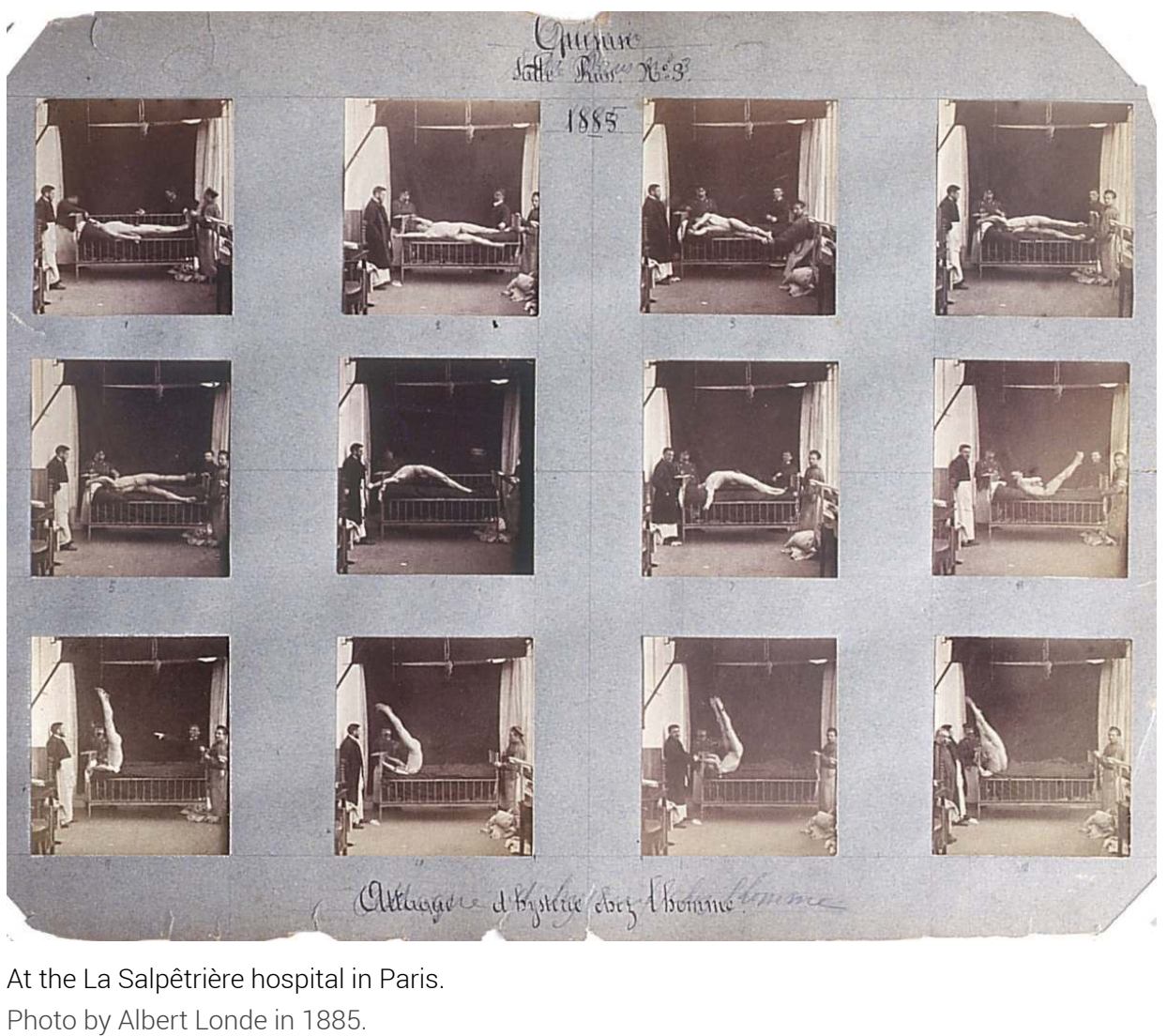

The key issue here is the way in which the photographic and graphical recording of sequences of movement was approached. The aim of these systematic recordings was not unlike de Martino's attempts to portray movement sequences and choreographies of ecstatic behavior and states of trance in Southern Italy in the late 1950's - to discern patterns, or rather, to reveal a standardized choreography, through which it was believed that the illness itself could be decoded.

Between 1876 and 1880, the Salpêtrière even founded its own journal with photographs taken by Londe and others, notably Charcot's student Paul Régnard, entitled L'Iconographie photographique de la Salpêtrière [The Photographic Iconography of the Salpêtrière] to document and further Charcot's methodological approach concerning visual manifestations of hysteria. The journal was later published in a multivolume album of the 
same title with the objective to produce a kind of illustrated inventory of the moment of crisis (Bourneville and Régnard 1878). The visual catalogue of the photographs included poses, attacks, screams, deliriousness, and, last but not least, states of ecstasy (Gilman 1982: 194-204). The journal issues also featured direct comparisons of the hysterics' photographs with images from classical art, e.g., Renaissance and Baroque paintings, depicting religious bliss and/or spiritual possession. The inclusion of these comparisons, authored by Paul Régnard, suggests that the photographic style adopted was influenced by artistic depictions, so that the presentation of 'hysterics' followed archetypal portrayals of religious mania in art history (Bourneville and Régnard 1880 [1878]; Poggi 2005).

But it was Charcot himself who forged a connection between religious melancholy, rapture, mystic visions, spirit possession and forms of mental illness (especially hysteria), by retrospectively applying his modern conceptualization of illness to depictions and reports of witch-hunts, as well as to antique artworks (Charcot and Richer 1887; for an analysis thereof see also Bronfen 1998; Didi-Huberman 2003). In so doing, he offered a secular explanation for phenomena that had been hitherto interpreted religiously. He sought visual evidence to support his conjecture that modern hysterics' symptoms were equivalent to those that had been experienced by Catholic mystics since medieval times, and claimed to have found such evidence in the hysterics' poses, which he interpreted as mimicry or parodies of religious experiences including worship, religious ecstasy, possession and even crucifixion (Charcot and Richer 1887; see also Schmaus 2009: 425). ${ }^{10}$

Période Terminale - Extase (Final Phase - Ecstasy)

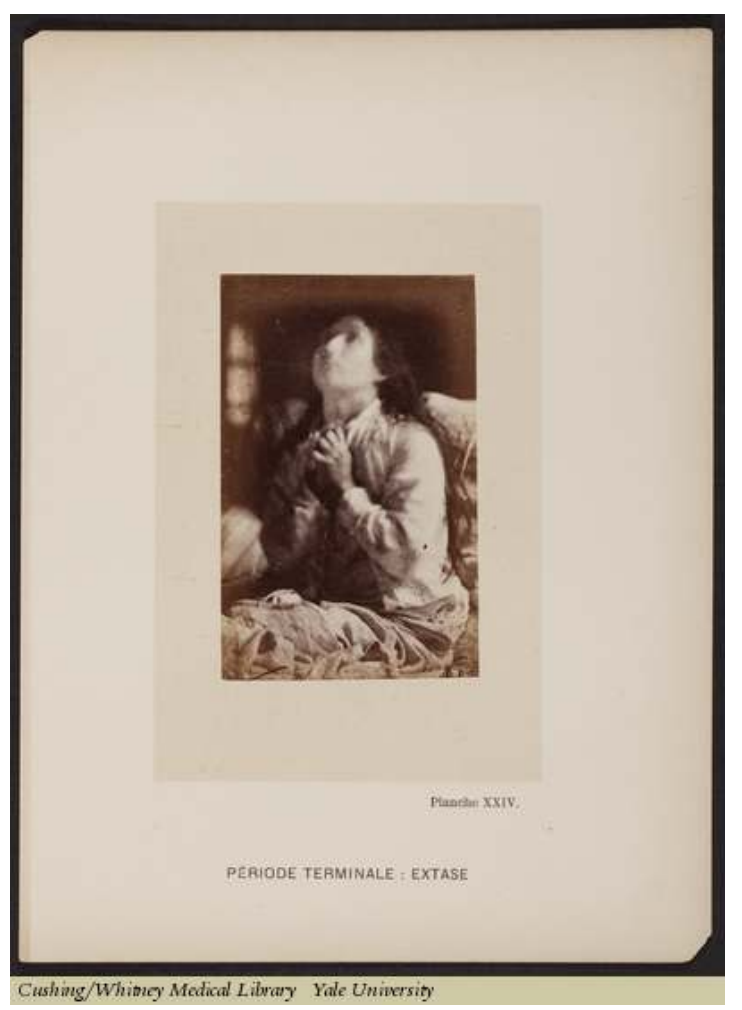

Photo by Paul Régnard in 1876, Albumen Print.

In the foreword to their 1887 publication Les demoniaques dans l'art [The Demoniacs in Art], in which Jean-Martin Charcot developed and elaborately illustrated this theory, he and 
his colleague Paul Richer relate how their use of plaster casting, pencil, paintbrush, and photography aids the "notation of all bodily postures and physiognomic differences, since text alone cannot capture all the visible effects of this alienating and horrendous illness." (Charcot and Richer 1887: XII, translation M.S.). ${ }^{11}$ Richer produced sketches (from live 'models' and from photographs) showing the different poses and stages of hysterical fits, and drew up a "synoptic table" in which he collated them systematically into categories entitled "attitudes passionelles" ["passionate postures"]. Describing the hysterical women, Charcot and Richer wrote that their "gaze is so honest that even the most talented actresses could barely offer a more convincing portrayal, nor could the greatest artist find a more worthy model." (Charcot and Richer 1887: 109). ${ }^{12}$

The digitized collection Iconographie photographique de la Salpêtrière entailing 119 images has been put online by the Harvey Cushing and John Hay Whitney Medical Library at Yale University and can be viewed here: http://whitney.med.yale.edu/gsdl/collect/salpetre/ (accessed December 17, 2016).

The highly sexualized nature of the images is conspicuous and many of the depicted poses are quasi-pornographic, mingling sexual and neurotic delirium. The camera turns into a tool for a play of gazes, in which the female patients are presented as vulnerable objects of (male and medical) desire yet simultaneously gaze seductively back into the camera using it as a tool of self-representation and hence (potential) empowerment.

\section{Début D'Une Attaque Cri (Start of a Scream Attack)}

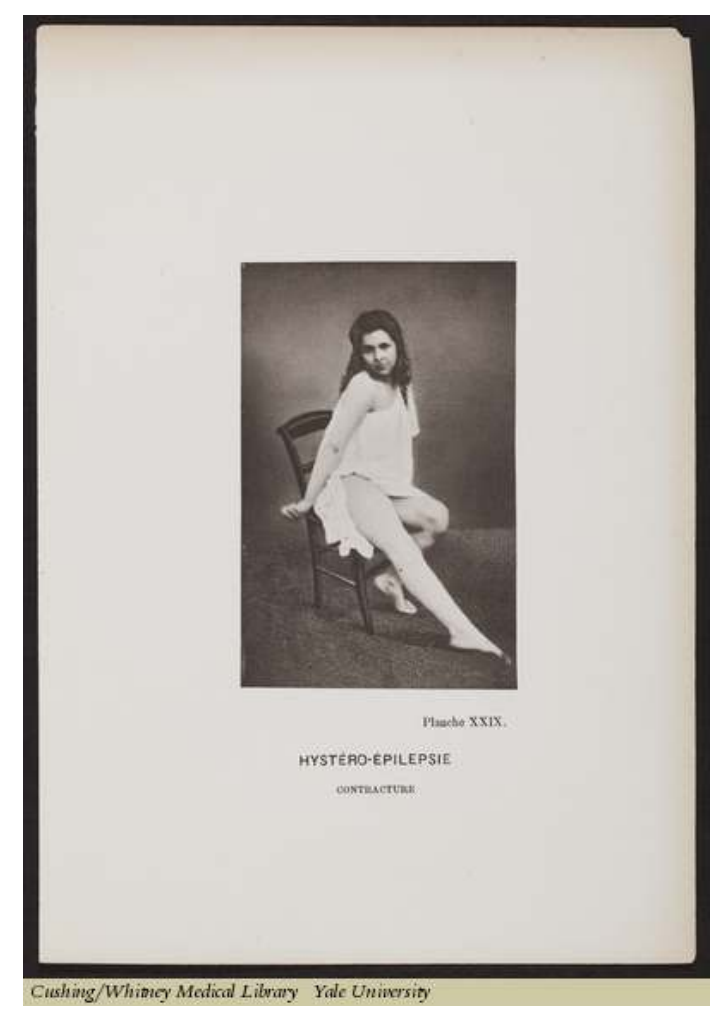

Photo by Paul Régnard in 1878 


\section{"Attitudes Passionelles": Theatricicality and Public Performances of Deviance}

One pose that appears repeatedly in the photographs is the so-called arc-de-cercle; a position in which the depicted woman lies on her back and raises her pelvis, arching her back.

Attaque Hystéro-Épileptique Arc De Cercle (Hysteric-Epileptic Attack, Arc-de-Cercle)

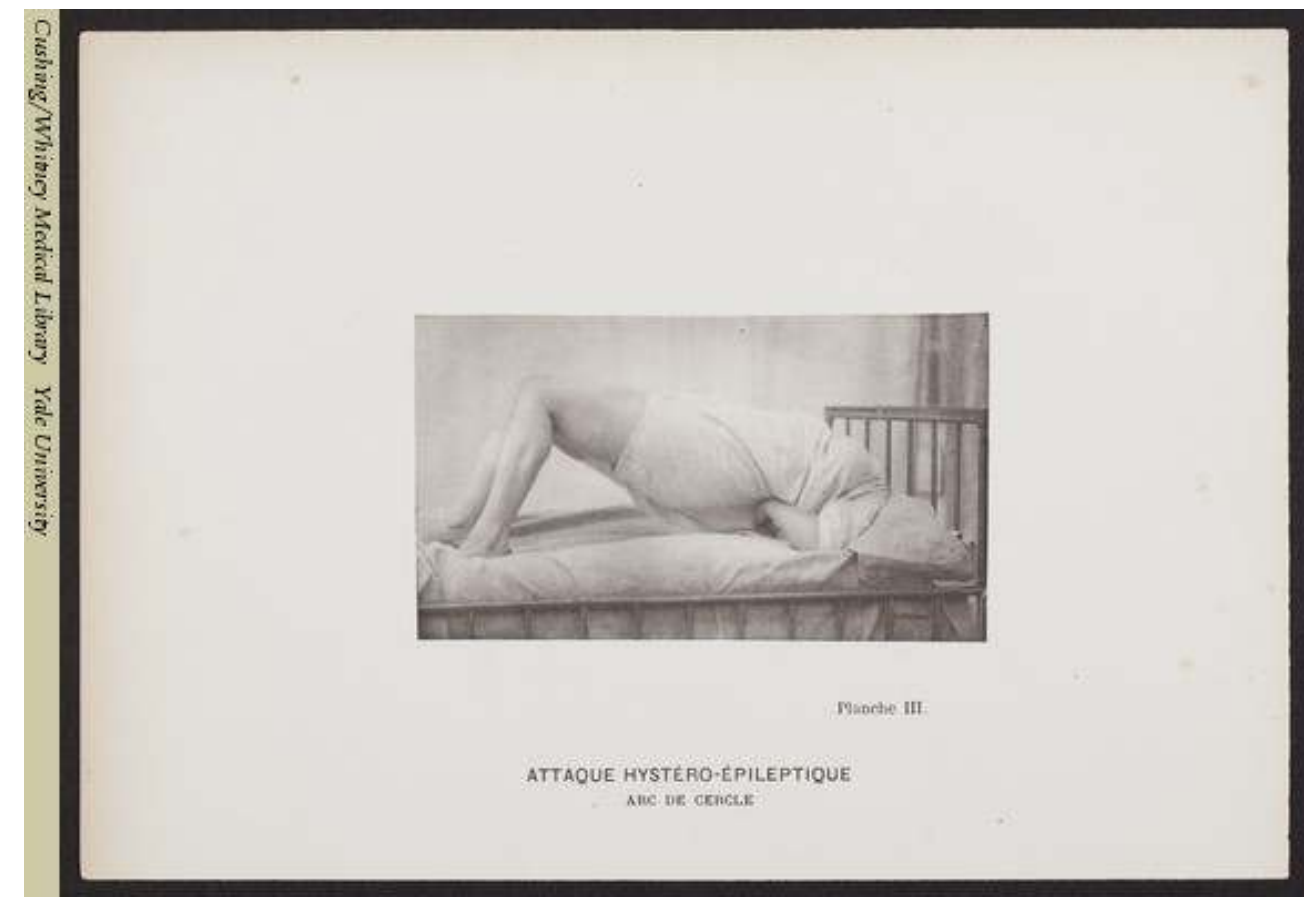

Photolithograph

Photo by Paul Régnard in 1880 
Contortion Phase (Arc-de-cercle)

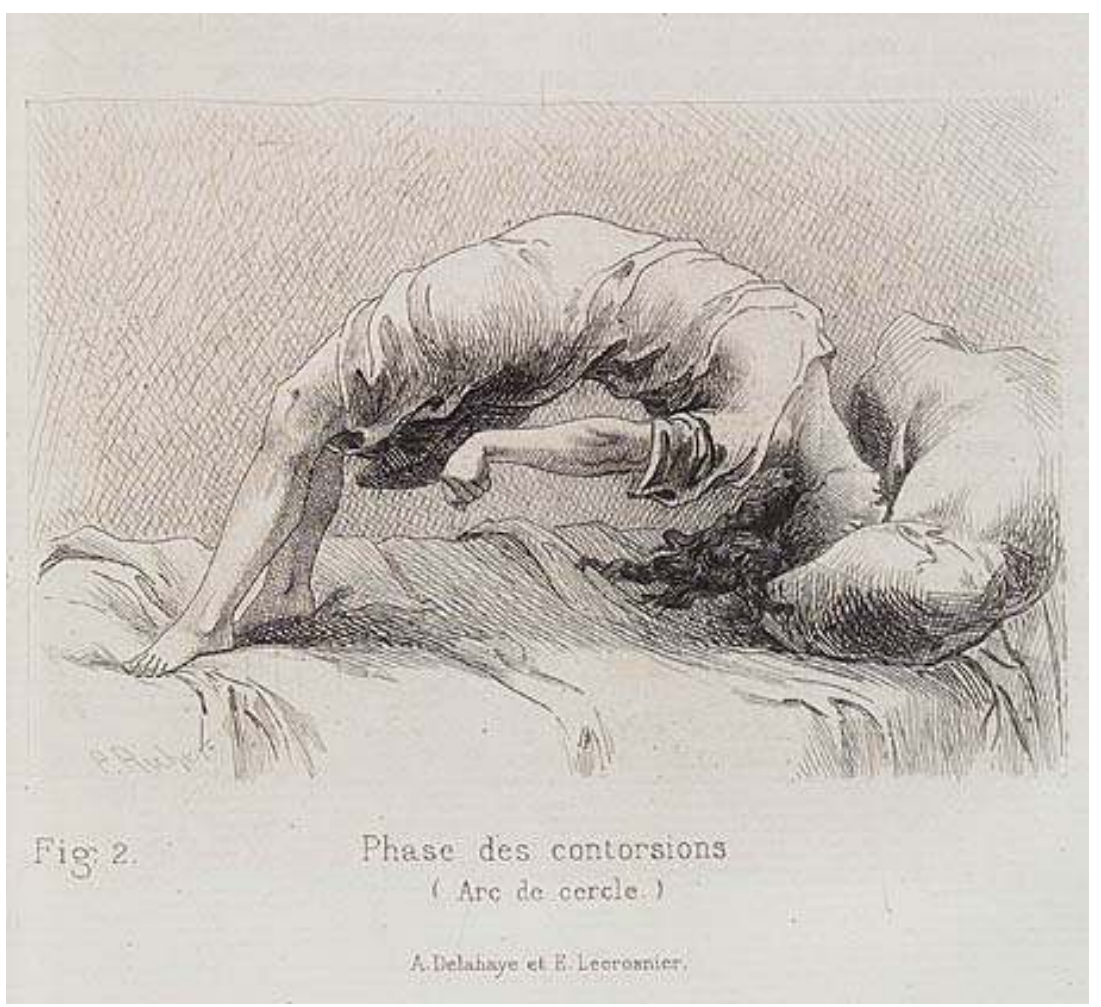

Drawing by Paul Richer in 1885

It is well known that Charcot publicly presented his patients to photographers and lecture audiences, and artificially induced their fits - by means of touch, olfactory stimuli, sounds or colors - for spectators to watch. According to Charcot, hysterics were particularly susceptible to suggestive influence and were therefore particularly easy to hypnotize. 
Une leçon clinique à la Salpêtrière [A Clinical Lesson at the Salpêtrière]

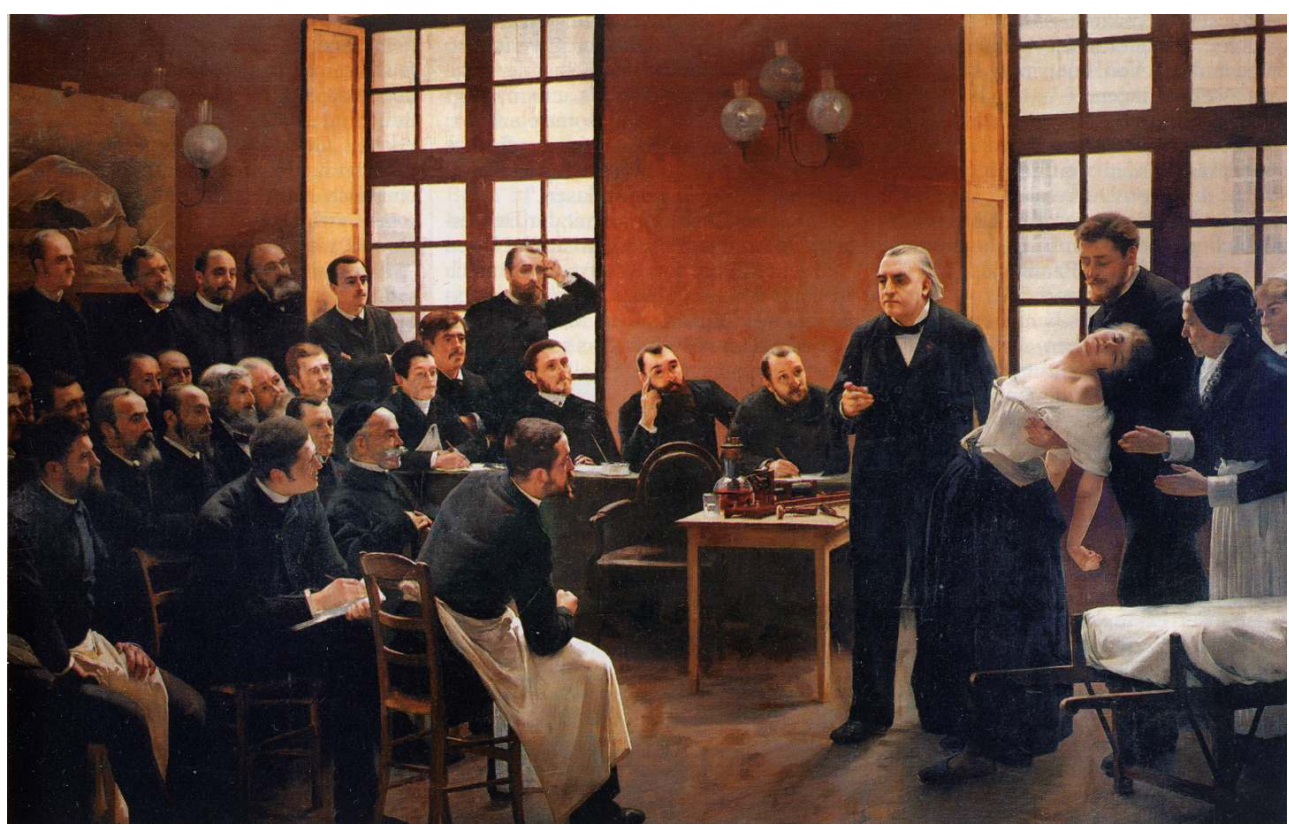

depicting Jean-Martin Charcot presenting the renowned hysteric "Blanche" (Marie Wittman) in a clinical lecture.

On the rear wall of the lecture room Brouillet reproduces a charcoal drawing entitled Periode de contortions [During the contortions], by Paul Richer (1878) depicting a convulsing woman. The pose in the drawing signifies the classic arc-en-cercle posture that Richer in turned reproduced from the photographs taken of "hysterics" in the Salpêtrière. The person depicted in a prominent position the front on the left dressed in a white apron, is the photographer Albert Londe.

Peinture à I'huile by André Brouillet in 1887

31 The public presentations and photography sessions also offered the patients themselves a platform where they could finally express their suffering and symptoms (Hustvedt 2011). In her apt summary of Didi-Huberman's arguments on the role photographic iconography in the "invention of hysteria", Elisabeth Bronfen highlights the "reciprocity of fascination" that characterized the Salpêtrière:

Doctors, insatiably seeking images of hysteria (be these live performances or photographic representations) and hysteric patients, complying with this spectacle, outmatching each other with the theatricality of their body poses, came together to stage a scene where hysterical suffering could be invented and fabricated as an art form, both as a spectacle and as an image (Bronfen 1998: 190).

The clinic and lecture halls in which the women were "presented" to medical offspring and the interested public turned into stages for theatrical performances in which the women enacted the (imitations of) poses and contractures that were perceived as typical for 'hysteric' patients at the time.

News of Charcot's studies also reached Italy, and in 1885 his lectures were translated by Dr. Domenico Meliotti and published as Lezioni cliniche dell'anno scolastico 1883-84 sulle Malattie del Sistema Nervoso [Clinical lectures of the 1883-84 academic year on Diseases of the Nervous System] (Meliotti 1885; Poggi 2005: 54). Like the Salpêtrière, Venice's San Clemente Hospital also commissioned the production of thousands of photographs of mentally ill women. In 1884 Augusto Tebaldi, Professor of Psychiatry in Padua, published a study on physiognomy and deviation, which included an appendix that showed numerous images of delirium in art. Then, in 1890, Gaetano Rummo (one of Charcot's 
translators) published the book Iconografia fotografica del Grande Isterismo-Istero-Epilessia [ Photographic Iconography of the Great Hysteria-Hysteric Epilepsy], which was dedicated to Charcot and included series of photographs presented in the style of Régnard's Iconographie photographique de la Salpêtrière (Rummo 1890; see also Poggi 1995: 55). ${ }^{13}$

Iconografia fotografica del Grande Isterismo-Istero-Epilessia (Photographic Iconography of the Great Hysteria-Hysteric Epilepsy)
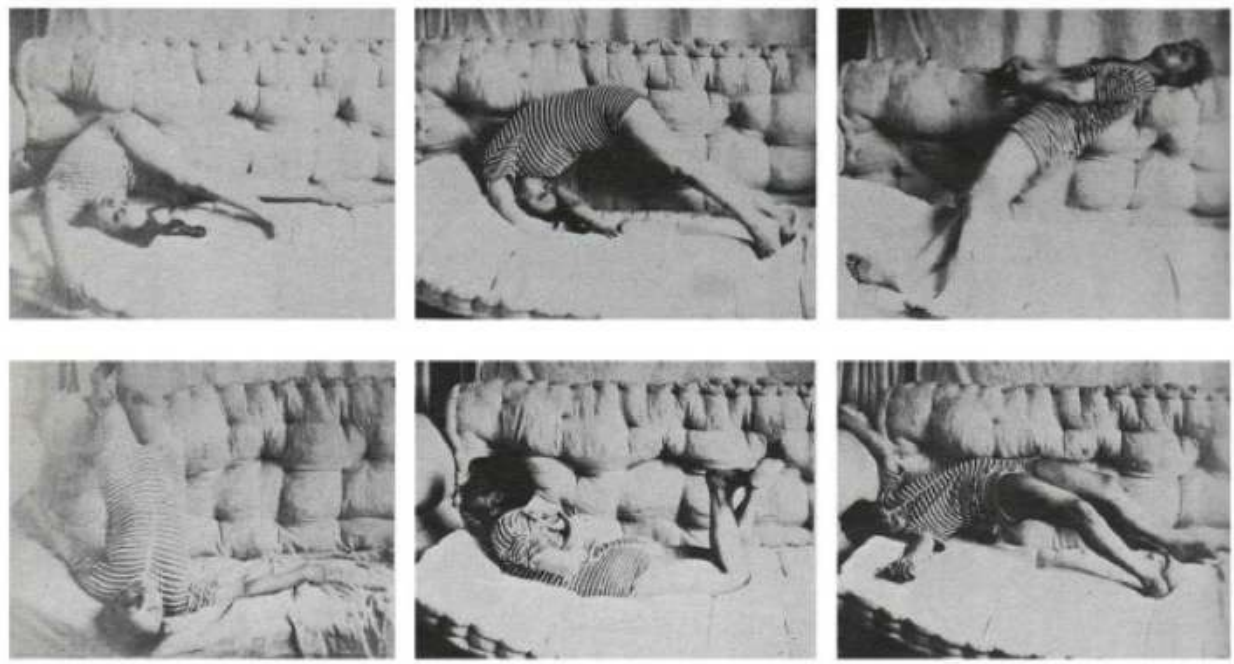

PHOTOS BY GAETANO RUMMO IN 1890 public spectacle of anatomy theatres - going back to the Italian Renaissance where anatomic anomalies, autopsies and body sections were openly displayed - to the public realm of the cinema screen in the early $20^{\text {th }}$ century (Holl 2005: 218). ${ }^{14}$ Interestingly, the New York Times review also favorably remarks on the technological innovation of capturing the corporeal language of gesture and movement. Stating "[w]hile the professor is explaining each case the cinematograph is at the same time reproducing the 
peculiar movements of which it is impossible to give an idea by a simple photographic plate", the reviewer highlights the superiority of the cinematograph in comparison to Albert Londe's chronophotographies (New York Times 1908; see also Strauven 2008: 279). 15

Analyzing the development of the medical gaze through various media technologies, German media scientist Ute Holl draws attention to the difficulty of translating the film images into language and written text:

... if the film NEUROPATOLOGIA [sic] is classified in historical medical terms, it can be viewed as the presentation of a hysterical fit. From the perspective of film dramaturgy, however, it could be just as well described as an expressionistic drama, a love triangle: a masked woman stands between two men, gazes and gestures are exchanged, the masked character is thrown, fighting, onto a bed; writhing, she tries to resist the force of one of the men; later she relaxes. The two aspects of this film cannot be separated. The medical content could not be made visible without the theatrical, the medical stage on which it is performed" (Holl 2005: 217)

The female patient, whose fit was provoked by pressure applied to her lower abdomen, wears a mask to hide her identity. Yet the mask also serves to direct viewers' attention to her, and adds a carnivalesque sense of absurdity to the scene. It is at this point that science becomes part of an entertainment industry. Another thing that is new, is that in La nevropatologia the medium of film is not used as a diagnostic or organizing tool or even for illustrating an affliction, but becomes in itself a means of evidence that replaces conventional anamnesis. It is safe to say that chronophotography and cinematography paved the way for the filmic mise-en-scène of neurophathologies and/or (neuropathological) ecstasy as "imaginary afflictions."

\section{De Martino's Atlas of Corporeal Postures and Gestures}

It is very likely that Ernesto De Martino was at least aware of, if not familiar with, the French and Italian medical photographs described above. Certainly, extraordinary iconographic parallels emerge between both, the catalogue of photographed and handdrawn "attitudes passionelles" produced in the Salpêtrière and De Martino's efforts to compile a visual encyclopedia of ritualized poses and emotional states during Southern Italian tarantella trance dancing and ecstatic saint veneration as well as ritual lament in Griko (ethnic Greek) communities in the Salento (Grecia Salentina). ${ }^{16}$

De Martino's ethnographic research focused upon techniques of the (female) body and the body as a mediator between internal feelings and their external expression, between the psyche and the body's corporeality. His personal notebooks from the time before his first Salento excursion contain drawings and sketches of possessed states and lamentations for the dead (Signorelli and Panza 2011; Pisapia 2013a; 2013b). The images consist of stick-figures, some of whom are kneeling with open arms, as well as detailed mimetic typologies of lamenting women. The sketches of gestures are labeled with terms such as "Anger", "Hunger", "Libido", and "Amnesia"; some of the drawings have been drawn over and corrected, while others precisely illustrate ritual poses that De Martino had not yet seen for himself (Pisapia 2013a: 17).

41 These were not drawings produced during research, but rather reproductions that he had reproduced by copying illustrations in books by then-contemporary German works on classical antiquity or from illustrations of ancient Greek vases. It is not entirely clear 
whether these sketches were De Martino's way of preparing himself for that which awaited him in the field, or whether they were early studies of a catalogue of movements. In any case, these hand-drawn studies portraying formulaic gestures and expressions of emotion, which De Martino presumed were universal, do exhibit remarkable similarities to Paul Richer's sketches and the series of images produced by Paul Régnard in his quest to catalog the "attitudes passionelles" (Bourneville and Régnard 1878; Charcot and Richer 1887).

In his 1958 classic study of "techniques of lament" (tecnica del piangere) Death and Ritual Lament in the Ancient World, De Martino appended a "Figurative Atlas of Mourning" (Atlante figurato del pianto) comprising sixty-six images, including photographs, film stills drawn from film strips, reproductions of pottery, etc. of lamentations (Pisapia 2013: 18). ${ }^{17}$ This visual appendix brings together examples of modern ritual lament in the form of "folkloric" photographs (i.e. photographs of Southern Italian women performing and reenacting classic gestures and poses of mourning that De Martino considers as directly linked to antiquity) with images from ancient and medieval art, in order to highlight the mimetic quality in ancient gestures and as well as in ecstatic states (Amelang 2005: 10). ${ }^{18}$ His intention in assembling an archive of gestures depicting contemporary 'artificial', staged performances as continuations of ancient ritual lament was not only to bring ancient rites back to life or to highlight the performative and resilient character if these practices, but to establish a genealogy of ritual mimicry. "Folkloric documentation", he argues, "allows us to see, in all its dramatic obviousness, what the ancient documents only allow us to glimpse or imagine, i.e. the lamentation as an active rite." (De Martino 2000 [1958] 58-59, translation Pisapia 2013a: 18). ${ }^{19}$ Using reenactments as an aid to the imagination, De Martino developed an intuitive appreciation of the sensorial aspects of ritual performance and of what, in Foucauldian terminology, would later be coined as "aesthetics of existence" or "technologies of the self."

The first short films produced in this way are 16mm recordings by Franco Pinna entitled Dalla culla alla bara [From Gradle to Grave] dating from 1952 (which is now considered to be lost), as well as the 3-minute documentary Lamento funebre [Funerary Lament] by Michele Gandin..$^{20}$ In 1954, four years before the publication of Death and Ritual Lament in the Ancient World (De Martino 2000 [1958]), Michele Gandin had already staged a lament with the two performers Grazia Prudente and Carmina Di Giulio in the Lucanian village of Pisticci. Although such lamentations traditionally took place indoors, in closed spaces usually in the home of the deceased - Gandin chose to record outside; not only for better lighting but also because the bare, moon-like Lucanian landscape added to the drama of the lament (cf. Marano 2007). A formalized and aestheticized mise-en-scène of a mourning ritual, these recordings focus on body techniques, facial expressions and gestures - the "expressive codes" (Gallini 1999: 18) - of the presenters. The short film sequence was originally intended to be the opening piece of the "Cinematographic Encyclopedia of Knowledge" that De Martino planned, but never completed. ${ }^{21}$

Jasmine Pisapia has highlighted the importance of "living documents" in the study of funerary lamentations in Death and Ritual Lament in the Ancient World, "which, thanks to their visual and corporeal presence, gave the researcher the enargeia [...] to fully understand the phenomenon" (Pisapia 2013a: 19). The crucial role played by reconstruction and reenactment in the De Martino's research practice was not limited to studying gestures and poses of ecstatic ritual mourning, but also comprised of the study of choreographies during trance-like expression of personal crisis such as in Apulian 
tarantism. A year after their research trips, in the summer of 1960, renowned music anthropologist and filmmaker Diego Carpitella returned to Galatina on his own and filmed an 'authentic' home therapy by Maria of Nardò, one of the most famous tarantate, along with another episode, the "artificial reconstruction" of music therapy. These recordings to which Carpitella added his own on-site sound recordings later on, were published under the title Meloterapia el tarantismo. The 16-mm material has recently been restored and is the first cinematographic documentation of Apulian tarantism ever.

This media file cannot be displayed. Please refer to the online document http:// journals.openedition.org/anthrovision/2409

Url: https://www.youtube.com/watch?v=Gs2jl5VZWz8).

In the same year, Gianfranco Mingozzi filmed the 18-minute documentary La Taranta in Nardò and Galantina that was released in $1962 .{ }^{22}$ Once again, the subject is the reconstruction of a so-called "home therapy", in which musicians gather in the home of a possessed tarantata to perform a therapeutic cycle of choreographed dances known as a ciclo coreutico. ${ }^{23}$

This media file cannot be displayed. Please refer to the online document http:// journals.openedition.org/anthrovision/2409

Url: https://vimeo.com/175932237

\section{Nachleben of De Martino's Images}

The manifold images that were produced during De Martino's expeditions to the South, developed a remarkable Nachleben ("afterlife") - also in the sense of a "survival", but mainly in Warburg's original sense as recurring symbolic and corporeal iconographies (Didi-Huberman 2016 [2002]). The decades that followed De Martino's original expeditions to the South saw numerous rivisitazioni, or re-visitations, mainly by Italian researchers, who intended to follow the footsteps of the master. These revisits, which also initiated a 'revival' of the fascination with the Mezzogiorno as imaginary land of 'pure' passions where ancient traditions were still genuinely lived, resulted in the production and circulation of the paradigmatic images of tarantuled women, curled up in arc-de-cercle positions (Chiriatti 1995; Chiriatti and Nocera 2005; Pizza 2015). ${ }^{24}$

In my own improvised rivisitazioni, I am mainly interested in the circulation or Nachleben of the images produced in the context of De Martino's research, as well as in the performative and mimetic qualities not only of the staged phenomena itself, but of the recording devices and media technologies involved. In the summers of 2012, 2015 and 2016, I had the chance to experience at first hand tarantella possession dances in the piazza in front of Galatina's chapel of St. Paul as well as "rievocazioni storice dell'antico rito del trarantismo" ("historical reenactments of the ancient rite of tarantism") in semiprivate courtyards in town. The performances themselves are best described as embodied reenactments; young women, amongst them Vincenza Magnolo and Simona Indracollo, (and at occasion also a few men) re-enacted the screams, movements, and facial expressions of Maria of Nardò, the tarantata who, all those years ago, had been interviewed by De Martino, photographed by Franco Pinna, and filmed by Gianfranco 
Mingozzi and Diego Carpitella. Dressed in white nightdresses, they writhed on the ground before me in time with the pizzica rhythm, crawled on all fours, arched their backs, twisted, stamped, moaned, and danced, and span ever faster, until, with eyes rolled, finally collapsed... and then began to dance again. The musicians and the 'performers' were surrounded by dozens of onlookers, who compared their judgments of the performance's authenticity.

\section{The performer's arc-de-cercle}
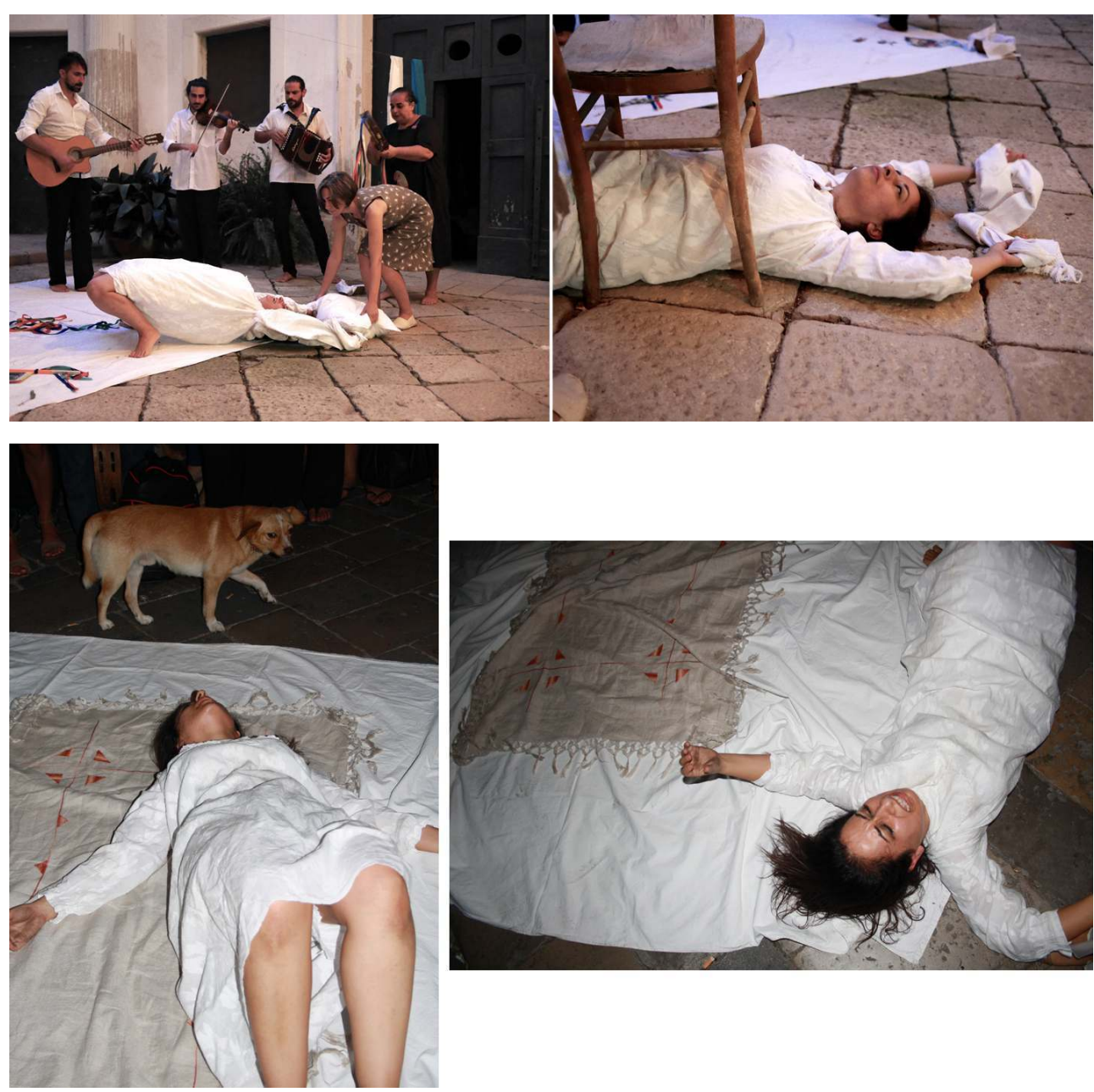

The performer's arc-de-cercle shown here is unmistakable, highlighting the "circulation of images" that has continued over several decades, across a diverse range of media.

Photos by Michaela Schäuble and Anja Dreschke in 2012 and 2016

In the background, next to the chapel, Mingozzi's Film La Taranta was screened; and it was obvious how the photographers whom I observed in 2012, 2015 and 2016 did their best to cite earlier photographs and to capture the same scenes and poses that had been photographed by Franco Pinna, André Martin and others before them - thus contributing to the stylized iconographic catalogue of Apulian tarantism.

51 The women who imitate(d) the tarantate had to and have to study the available images of ecstasy in order to deliver a performance that is as 'authentic' as possible. In so doing, they follow (and uphold) the tradition of the visual and performative reproduction of existing images and poses. Like the performances of the female 'hysterics' in $19^{\text {th }}$ century Paris, the tarantate use their trances to make their crises and their subjective suffering 
public; through "practices of imagination" (Kramer 2005) that manifest in their body movements and postures they create a connection between invisible, or imaginary and visible realms. While Marie Wittmann alias "Blanche" became an iconic figure of hysterical femininity, Maria of Nardò became the iconic tarantata, who is now in turn mimicked by contemporary performers such as Simona Indracollo, who consciously reproduce the iconographic patterns of Apulian tarantism.

Poster advertising the "Historical Reenactment of the Ancient Rite of Tarantism"

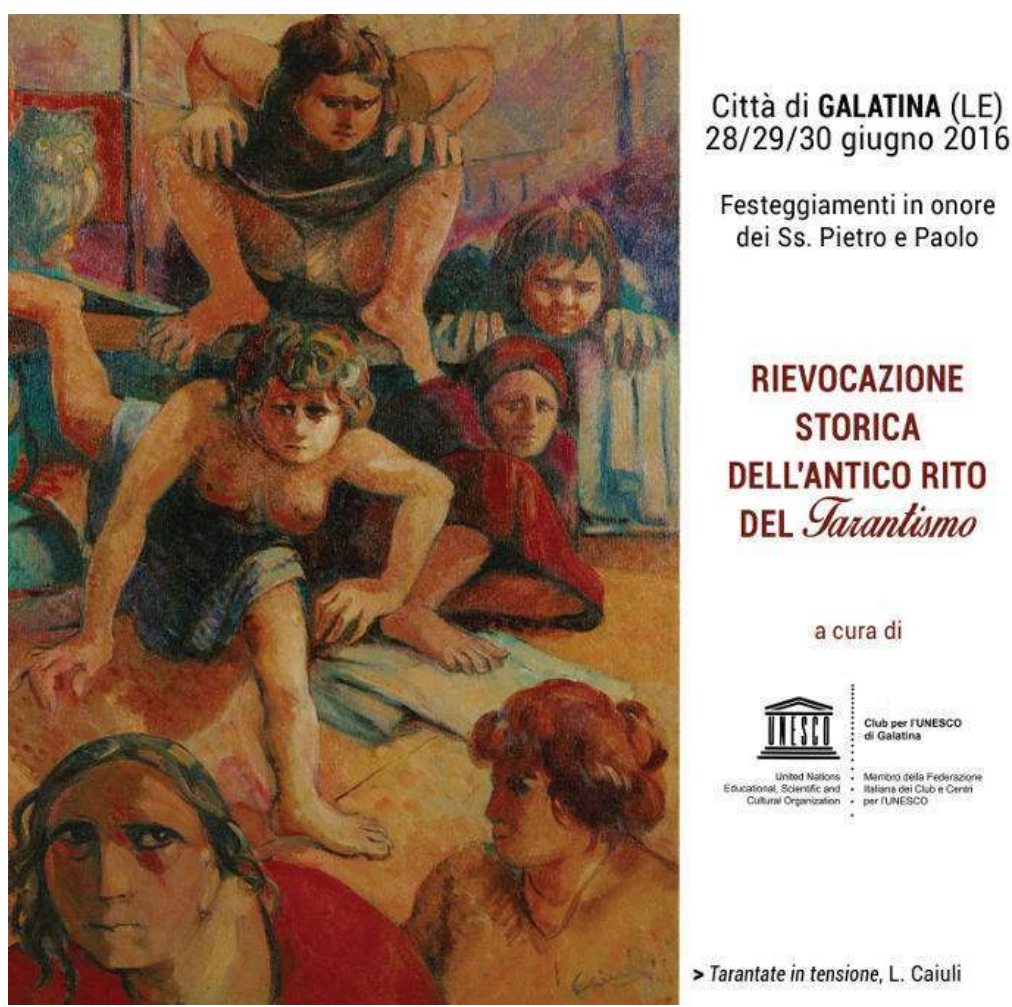

organized by the UNESCO Club Galatina. The painting by Apulian artist Luigi Cailuli (*1940) is entitled Tarantate in tensione [Tarantate in tension]

Poster by UNESCO 2016

I propose that in these performances the largely invisible suffering and the imaginary realm of spider possession are transferred to a virtual level, where the corporeal and sensuous experiences of an 'authentic' tarantata is simulated. But more is at stake here than in the case of a simulacrum, where the distinction between original and copy, signified and sign, has become indistinguishable. The 'original' spider exorcism recorded by De Martino's team was, even then, largely a re-enactment, as were the dances and choreographies, screams and facial expressions of the possessed women who were filmed by Diego Carpitella, Gianfranco Mingozzi and photographed by Franco Pinna and many others. Apulian tarantism itself can be seen as a repeatedly duplicated, stylized image that has begun to take on a life of its own.

Just like the enactment of symptoms that established a canon of hysterical poses and attitudes in $19^{\text {th }}$ century Paris did not render the symptoms themselves and the suffering of the afflicted women imaginary or unreal, the mimicking and the formation of certain stylized poses in Apulian tarantism and ritual lament as visible manifestation of the condition or suffering does not make the phenomenon itself fabricated. Rather, it could 
be shown by means of these examples that neither 'hysteria' nor Apulian ritual mourning nor tarantism demonstrate the ahistorical, fundamentally unchanging nature of "imaginary afflictions." The photographic depictions and drawings - images of ecstasy and affliction - can neither provide the ultimate proof for, nor an exhaustive explanation of these phenomena. Hence, to dance the tarantella is not to strive for the best possible replication of a template, just as the staged presentations do not primarily serve the documentation or reconstruction of a seemingly defunct phenomenon. Instead, the dances and rievocazione are enactments and performances in their own right that exhaust the creative potential of tarantism's expressive form and "offer [...] a perspective for imagining, hearing and watching what we lack imagination for", as stated by De Martino and quoted in this article's epigraph (De Martino 2005 [1961]: 36).

\section{BIBLIOGRAPHY}

\section{Books and articles}

Agosti, Giovanni and Maurizio Sciuto. 1990, "L’Atlante del pianto di Ernesto De Martino," in Riccardo Di Donato (ed.), La contraddizione felice? Ernesto De Martino e gli altri. Edizioni ETS, 185-195.

Amelang, James S.. 2005. Mourning Becomes Eclectic: Ritual Lament of the Problem of Continuity. Past \& Present 187: 3-31.

Bourneville, Désiré- Magloire et Paul Régnard. 1880 [1877, 1878, 1879-1880]. L'Iconographie photographique de la Salpêtrière. Paris: Delahaye https://archive.org/details/ iconographiepho00regngoog (accessed December 17, 2016)

Bronfen, Elisabeth. 1998. The Knotted Subject. Hysteria and its Discontents. Princeton, New Jersey: Princeton University Press.

Cascella, Daniela. 2012. Magic, Ritual, Lament: Ernesto de Martino. In En abîme, the Blog, Archive for July. https://enabime.wordpress.com/2012/07/23/magic-ritual-lament-ernesto-de-martino/ (accessed December 17, 2016)

Charcot, Jean-Martin and Paul Richer. 1887. Les demoniaques dans l'art. Avec 67 figures intergalées dans le texte. Paris: A. Delahaye et E. Lescrosnier.

Chiriatti, Luigi e Maurizio Nocera (eds.). 2005. Immagini del tarantismo. Galatina: il luogo del culto. Lecce: Capone Editore.

Chiriatti, Luigi. 1995. Morso d'amore. Viaggo nel tarantismo salentino. Lecce: Capone Editore

Dall'Olio, Mario.1908. La neuropatologia al cinematografo. La gazzetta di Torino (18. Feb. 1908)

De Martino, Ernesto. 1947. Inchiesta di «Quarto Stato» sul mezzogiorno. Terra di Bari (in collaborazione con M. Potenza). Quarto Stato, 25-26, 30 gennaio-15 febbraio: 32-36.

De Martino, Ernesto. 2000 [1958] Morte e pianto rituale nel mondo. Dal lamento funebre antico al pianto di Maria. Torino: Bollati Boringhieri. 
De Martino, Ernesto. 2002 [1954].“I Lamenti funebri e l'esperienza arcaica della morte. in Panorami e Spedizioni. Le trasmissioni radiofoniche del 1953-54 di Ernesto de Martino. Luigi M. Lombardi Satriani and Letizia Bindi (eds.). pp. 68-75. Torino: Bollati Boringhieri,

De Martino, Ernesto. 2005 [1961]. The Land of Remorse, [La terra del rimorso. Contributo a una storia religiosa del Sud]. London: Free Association Books.

Didi-Huberman, Georges. 2003 [1982]. Invention of Hysteria. Charcot and the Photographic Iconography of the Salpêtrière Cambridge: MIT Press

Didi-Huberman, Georges. 2012. Peuples exposés, peuples figurants: l'oeil de l'histoire, 4. Paris: Éditions de Minuit.

Didi-Huberman, Georges. 2016 [2002]. The Surviving Image. Phantoms of Time and Time of Phantoms: Aby Warburg's History of Art. Translated by Harvey Mendelsohn. University Park, Pennsylvania: Penn State University Press.

Faeta, Francesco. 2003. Strategie dell'occhio: Saggi di etnografia visiva. Milano: FrancoAngeli, Flaherty, Gloria. 1992. Shamanism and the Eighteenth Century. Princeton: Princeton University Press.

Forgacs, David. 2014. Italy's Margins. Social Exclusion and National Formation since 1861. Cambridge: University Press: Cambridge.

Gallini, Clara. 1983. La sonnambula meravigliosa: Magnetismo e ipnotismo nell'Ottocento italiano. Milano: Feltrinelli

Gallini, Clara. 1999. Percorsi, immagini, scritture. In I viaggi nel Sud di Ernesto de Martino, Clara Gallini and Francesco Faeta (eds.). pp.9-48. Torino: Bollati Boringhieri.

Gallini, Clara and Francesco Faeta (eds.). 1999. I viaggi nel Sud di Ernesto De Martino. Fotografie di Arturo Zavattini, Franco Pinna e Ando Gilardi. Torino: Bollati Boringhieri.

Gilman, Sander L. 1982. Seeing the Insane. Lincoln, London: Nebraska University Press.

Gilman, Sander L. 1993. The Image of the Hysteric. In Hysteria Beyond Freud. Sander L Gilman. et al (eds.):. Berkeley, Los Angeles, London: University of California Press, 345-452.

Gilman, Sander L. 2014 [1976]. The Face of Madness. Hugh W. Diamond and the Origin of Psychiatric Photography. Brattleboro, Vermont: Echo Points \& Media.

Gisi, Lucas Marco. 2007. Einbildungskraft und Mythologie. Die Verschränkung von Anthropologie und Geschichte im 18. Jahrhundert. Berlin, New York: Walter de Gruyter.

Holl, Ute, 2006. Neuropathologie als filmische Inszenierung. In Konstruierte Sichtbarkeiten. Wissenschafts- und Technikbilder seit der frühen Neuzeit. Martina Heßler (ed..) Pp. 217-240. München: Wilhelm Fink Verlag

Hufeland, Christian Wilhelm. 1794. Gemeinnützige Aufsätze zur Beförderung der Gesundheit des Wohlseyns und vernünftiger medicinischer Aufklärung. Band 1. Leipzig: Georg Joachim Göschen.

Hustvedt, Asti. 2011. Medical Muses. Hysteria in Nineteenth-Century Paris. London et al.: Bloomsbury Kramer, Fritz. 2005. Schriften zur Ethnologie. Suhrkamp, Frankfurt am Main

Londe, Albert. 1893. La photographie médicale. Application aux science médicales et physiologiques. Pref. by Charcot. Paris: Gauthier-Villars.

Marano, Francesco, 2007. Il film etnografico in Italia. Bari: Edzioni di Pagina. 
Meliotti, Domenico. 1885. Lezioni cliniche dell'anno scolastico 1883-84 sulle malattie del sistema nervoso. Milano: Francesco Vallardi.

New York Times. (1908). Moving Pictures of Clinics.; Prof. Negro Successfully Uses Them in Demonstrating Nervous Diseases. The New York Times. February 23, 1908 http:// query.nytimes.com/gst/abstract.html?res=9C05E4D81F3EE233A25750C2A9649C-946997D6CF (accessed December 17, 2016)

Panza, Valerio. 2006. Comparare antico e moderno: l'atlante del pianto di Ernesto De Martino. In Comparatisimi e filosofia. Mario Donzelli (ed.). Pp. 197-217. Napoli: Luguori.

Pisapia, Jasmine. 2013a. Archives of Pathos. Image and Survival in Ernesto De Martino's Interdisciplinary Ethnography. Visual Ethnography, Vol. 2 (1): 1-26.

Pisapia. Jasmine. 2013b. Image et survivance en anthropologie visuelle. Ernesto De Martino et l'ethnographie interdisciplinaire. In : Mémoire présenté à la Faculté des Arts et des Sciences en vue de l'obtention du grade de M.A. en Littérature comparée, Université de Montréal http:// hdl.handle.net/1866/10628 (accessed December 17, 2016)

Pizza, Giovanni. 2015. Il tarantismo oggi. Antropologia, politica, cultura. Roma: Carocci editore Poggi, Christine. 2005. Picturing Madness in 1905: Giacomo Balla's "La pazza" and the Cycle "I viventi". Res Anthropology and Aesthetics. Vol. 47 (Spring): 39-68.

Regener, Susanne. 2000. “Zwischen Dokumentation und Voyeurismus. Fotografien psychiatrischer Patienten“, in Fotogeschichte, Jg. 20, Heft 76: 13-24.

Regener, Susanne. 2010. Visuelle Gewalt. Menschenbilder aus der Psychiatrie des 20. Jahrhunderts. Bielefeld: Transcript.

Rummo, Gaetano. 1890. Iconografia fotografica des Grande isterismo-Istero-Epilessia, omaggio al Prof. J.M. Charcot. Napoli: Clinica Medica Propedeutica di Pisa.

Schmaus, Marion. 2009. Psychosomatik. Literarische, philosophische und medizinische Geschichten zur Entsteung eines Diskurses (1778-1936). Tübingen: Niemeyer Verlag.

Signorelli, Amalia and Valerio Panza (eds.). 2011. Ernesto de Martino. Etnografia Del Tarantismo Pugliese. I Materiali Della Spedizione Nel Salento Del 1959. Lecce: Argo.

Stimilli, Davide. 2015. The Luxury of Tears: Warburg and De Martino on Klage and Lamento. Lecture presented at the Zentrum für Literatur und Kulturforschung, Berlin, Germany, 11 July 2015.

Strauven, Wanda. 2008. "S/M". In: Mind the Screen; Media Concepts According to Thomas Elsaesser. Jaap Kooijman, Patricia Pisters and Wanda Strauven (eds.). Pp 276-287. Amsterdam: Amsterdam University Press.

Films

Carpitella, Diego.1960. Meloterapia el tarantismo.

Carpitella, Diego. Tarantismo nel Salento.

Gandin, Michele. 1954. Death and Ritual Lament in the Ancient World. 4,5 min.

Gandin, Michele. 1954. Lamento funebre [Funerary Lament] 4,5 min.

Gordon, Douglas. 1994-95. Hysterical. Video installation.

Koester, Joachim. 2007. Tarantism. 6,5 min. Film installation 
Mangini, Cecilia. 1960 Stendali https://www.youtube.com/watch?v=W8u0FGWgTpE (accessed December 17, 2016)

Mingozzi, Gianfranco. 1962. La Taranta. $18 \mathrm{~min}$.

Negro, Camillo (dir.) and Roberto Omegna, (camera). 1908. La nevropatologia [Neuropathology]

Negro, Camillo (dir.) and Roberto Omegna, (camera). 1918. Shell shock filmati all'Ospedale militare di Torino. 8 min. https://vimeo.com/119547503 and https://vimeo.com/119547502 (accessed

December 17, 2016)

Pinna, Franco. 1952. Dalla culla alla bara [From Gradle to Grave]

\section{NOTES}

1. A much shorter version of this article was first presented at the German-Italian symposium “L'altra condizione dell'Italia. Il 'sud posseduto': antropologie dei fenomeni di possessione tra Ernesto de Martino e Friedrich Nietzsche“ ["Italy's other condition. Anthropologies of 'possessed South' from Friedrich Nietzsche to Ernesto De Martino"] at Villa Vigoni, organized by Ulrich van Loyen. I would like to wholeheartedly thank Ulrich van Loyen and Stefano De Matteis for their valuable comments and their encouragement to elaborate on the argument. I am also particularly thankful to Anja Dreschke for her companionship and inspiring discussions during several research trips to Puglia as well as to Thomas Hauschild, Alexandra Rieder, Antonio Roselli and Jasmine Pisapia for their expertly feedback on my work and for sharing my fascination for the work of the registi demartiniani. I am also very grateful to Pip Hare for her translation from German.

2. The very first "spedizione etnografica" (ethnographic expedition) to Lucania in the early summer of 1952, during which Ernesto De Martino was accompanied by photographer Arturo Zavattini, resulted in the production of a corpus of 150 black and white photographs. This expedition was supported by the Centre for popular music of the Santa Cecilia Academy and of RAI television and preceded Alan Lomax's journey to Calabria and his photographs and recordings in August 1954 by two years (Cascella 2012). Later the same year, De Martino undertook a second expedition to more remote villages in Lucania, this time accompanied by photographer Franco Pinna, ethnomusicologist Diego Carpitella (who did sound recordings of songs and magic practices) as well as by his fiancé Vittoria de Palma, who enabled the team's access to women's lifeworlds. During this trip Pinna actually filmed some funeral laments on 16mm, but the footage did not survive (Forgacs 2014: 144). Between 1953 and 1956 the anthropologist conducted five more journeys to Southern Italy, mainly researching ritual lamentations and popular songs, during which his team refined their audio-visual research methods. On their last trip, in August 1956, Franco Pinna shot 341 photographs (only 12 out of which were in color). In May/June 1957 De Martino assembled his first interdisciplinary equip to study the "psychological misery" of the Southerners, and this time it was Ando Gilardi who took the pictures. For an annotated collection of these photographs, see Gallini and Faeta 1999.

3. The term "imaginary afflictions" or "afflictions of the imagination" refers to what the German physician Christian Wilhelm Hufeland termed as "Krankheiten der Einbildungskraft" in 1794. According to Hufeland, so-called "nervous illnesses" such as hypochondria, the vapors, and nerves - which he called "Imaginations- und Modekrankheiten" (afflictions of the imagination and popular afflictions) - share the same source and symptoms as states of bewitchment and possession. Hufeland assessed these afflictions as medically comprehensible and stated "[i]ndeed, I do not know a more frightful and a more real illness" (Hufeland 1794: 101, cited in Flaherty 1992: 107). He further suggested that these afflictions did not have a physical cause but were 
triggered by the imagination and could therefore only be cured through the imagination (Gisi 2007: 160). In contrast to psychologists such as Pierre Janet, Hippolyte Bernheim, Sigmund Freud and Jean-Martin Charcot, who all emphasized the role of the unconscious in mental illness and the susceptibility of the mentally ill to suggestion (and hypnosis), Hufeland explicitly refers to the imagination as both, the source and the potential cure for mental afflictions.

4. A contract, signed by both, Ernesto De Martino and Franco Pinna, dated June 15, 1959 clearly and meticulously states working conditions and sites, areas of responsibility, copyright issues and the payment oft he photographer. A similar "agreement of collaboration", stating her duties and limitations as photographer, was made out for and signed by Annabella Rossi on June 19, 1959 (Archive of the Associazione Internazionale Ernesto de Martino at the Bibliomediateca Accademia di Santa Cecilia, Box 18, Folder 7, personal archival research).

5. This was, for example, the case for Cecilia Mangini's film Stendali (1960) which De Martino only saw after its completion. Mangini had read De Martino's Morte e pianto rituale nel mondo antico on ritual lament and was strongly moved by it. She then travelled to Martano, a village in Grecia Salentina, where De Martino had previously conducted fieldwork and staged the scenes for her film in which she reconstructs the death of a young man and the ritual lament by his mother and the village women. The full film can be viewed here: https://www.youtube.com/watch? $\mathrm{v}=$ W8u0FGWgTpE

6. What should not be forgotten in this context is that women were usually paid for their mourning services - so the ritual lament is per se a performance and not necessarily an expression of individual, emotional crisis. "One of de Martino's points in Death and Ritual Lament is to show how the personal dimension of mourning is regained within the 'protected' and codified environment of the lamentation ritual. It is a constantly de-historicised and rehistoricised gesture, in transit between truth and fiction, between being there and being possessed" (Cascella 2012).

7. In her excellent analysis of the use of images in De Martino's expeditions, Jasmine Pisapia states that the shoot "was conducted in the ethnographer's room at the Cavallino bianco hotel, and the ritual performed was described by De Martino as having being done 'in vitro"' (Pisapia 2013a: 10).

8. Diamond's assumption shows some significant parallels to Hufeland's hypothesis that "imaginary afflictions" could best be cured through the imagination and his use of photography is a progression of Hufeland's prior experimenting with musical stimuli and "the flashing of mirrors" to induce, intensify and modify the symptoms of ecstatics and convulsives (Flaherty 1992: 108).

9. The German edition of Didi-Huberman's Invention de l'hystérie. Charcot et l'iconographie photographique de la Salpêtrière (1982) is entitled Die Erfindung der Hysterie. Die photographische Klinik von Jean-Martin Charcot (1997) - "The photographic clinic of Jean-Martin Charcot."

10. Christine Poggi notes that mimicry was a central element in the representation of hysteria (Poggi 2005: 52).

11. In the original version they write: “Au démoniaque hystérique, au possédé convulsionnaire pour lequel le médecin ne soupçonnait nul remède, et dont le prêtre ou le juge s' emparaient, convaincus qu'ils opéraient sure une âme hantée, a succédé un malade dont le crayon, le pinceau et la photographie notent toutes les attitudes, toutes les nuances de physionomie, venant ainsi au secours de la plume, qui ne peut tout décrire dans les effets extérieurs de cette étrange et cruelle maladie" (Charcot and Richter 1887: XII

12. The French original speaks of "une expression si vraie et si intense que les actuers les plus consommées ne sauraient mieux faire et que les plus grandes artistes ne sauraient trouver des modèles plus dignes de leur pinceau“ (Charcot and Richer 1887: 109). 
13. Notably, it was De Martino's research assistant Clara Gallini who put together a bibliography of Italian treatises on hysteria, hypnosis, and related phenomena (Gallini 1983; see also Poggi 2005: 54).

14. During the war years Negro continued his scientific film project at the Military Hospital in Torino, filming shell-shocked soldiers. The film „shell shock“ was released in 1918 and can be viewed online: https://vimeo.com/119547503 (part 1) and https://vimeo.com/119547502 (part 2) In autumn 2011, the Museo Nazionale del Cinema, in partnership with the Faculty of Neurosciences of the University of Turin, presented a new critical edition of the neuropathological films directed by Negro.

15. In his installation Hysterical (1994-95) video artist Douglas Gordon used scenes from La nevropatologia, projecting them on a double screen in loops, one performing in slow motion and one partly reversed to obtain a mirror effect. The projection on two tilted screens created a three-dimensional space for spectators to move through.

16. The Griko are believed to be remnants of the ancient Greek communities in Southern Italy, although there is dispute among scholars as to whether the Griko community is directly descended from ancient Greeks or from more recent medieval migrations during the Byzantine domination.

17. For more comparative work on De Martino's "Figurative Atlas of Mourning" see Agosti and Sciuto 1990, as well as, more recently, Panza 2006.

18. The atlas of gestures is reminiscent of Aby Warburg's unfinished Mnemosyne project, in which Warburg tried to identify and map what he believed were universal Pathosformeln (formulaic gestures and expressions of emotion). Although De Martino never directly referred to Warburg's last project, a number of scholars have drawn attention to strong parallels between the two atlases (Agosti and Sciuto 1990, Faeta 2003, Didi-Huberman 2012, Pisapia 2013a, 2013b among others). The connection was also discussed at an international conference entitled Mourning, Magic, Ecstatic Healing. Ernesto de Martino held at the Zentrum für Literatur- und Kulturforschung, Berlin, Germany (9.-10.07.2015), especially in the paper by Davide Stimilli."The Luxury of Tears: Warburg and De Martino on Klage and Lamento", 11 July 2015.

19. In the original it says: "[...] È ciò che la documentazione antica ci lascia soltanto intravedere o immaginare, cioè il lamento come rito in azione, la documentazione folklorica ce lo pone sotto gli occhi in tutta la sua evidenza drammatica [...]," (De Martino 2000 [1958] 58-59).

20. In addition to his numerous photographies, Franco Pinna also shot 300 meters of film footage of everyday practices and religious rituals in Salento. The recordings were originally to be exhibited together with the photographs of Pinna and audio recordings of Carpitella. But after the research, the recordings seem to have been lost and are still regarded as missing (Forgacs 2014: 144).

21. The laments that Franco Pinna photographed during his travels with De Martino between 1952 and 1956 have also been reconstructed and were performed especially for the anthropologist and his photographers. Only once, in August 1956 did the two witness an 'authentic' lament for the late Carolina Latronico in Castelsaraceno (cf Gallini 1999: 24).

22. Gianfranco Mingozzi's La Taranta (1962) is the best-known filmic depiction of tarantism and was nominated for an Academy Award in the documentary section in 1963. It is eighteen minutes long and its dramaturgic and narrative structure closely follows the structure of De Martino's written ethnography La terra del Rimorso (Land of Remorse, 2005 [1961]).

23. Not unlike Douglas Gordon's appropriation of medical footage of hysterical patients in his performance art piece Hysterical, conceptual artist Joachim Koester referred to historical recordings of tarantism in his $16 \mathrm{~mm}$ film installation Tarantism (2007). And although Koester is not directly using archival footage, in Tarantism dancers improvise spasms of tarantuled persons thus reenacting and mimicking the reenactments in the films made in the course of De Martino's Apulian expeditions (https://www.youtube.com/watch?v=q_uz_-YnauM). In 2008, an exhibition 
at the Musée départemental d'art contemporain de Rochechouart entitled Trances, brought this two art works together. The curators argued that "[...] Joachim Koester's Tarantism shows actors imitating the trance-like states witnessed in primitive dance rituals, faking convulsions not unlike those seen in Douglas Gordon's Hysterical. The title Tarantism refers to the folk dance from Southern Italy thought to have its origins in the spasms caused by the tarantula spider's bite. In a predominently Catholic country, the dance survives, some claim, as a remnant of ancient Dionysian practices" (http://www.e-flux.com/announcements/38838/trances/). And although speaking of "faking" the symptoms is a crude simplification of the phenomena, the exhibitionmakers highlighted an interesting parallel in these two cases with a clear reference to states of trance.

24. These iconographic images consist of photographs by several researchers and journalists, including Luigi Chiriatti, who annually photographed the spectacle of tarantism in Galatina from1970-1992, as well as photographs by Chiara Samugheo (1954), Angelo Colazzo (1972), Fernando Ladiana (1974), Paolo Longo (1976), Salvatore Congedo (1979), Carmelo Caroppo (1983), Fernando Bevilacqua (1994-2004), as well as the photographs by the psychiatrist-sociologist team Paolo Albanese and Paola Chiari from 1980 (Chiriatti and Nocera 2005: 67-119).

\section{ABSTRACTS}

This article analyzes the production of visual stereotypes of so-called "imaginary afflictions" (Hufeland 1794), defined as disorders that have no physical cause but are triggered by - and potentially cured through - imagination. Drawing on the well-known example of 'the hysteric' as paradigmatic trope in medical photography of the 19th and early 20th century, I detect and trace iconographies that are based on the assumption that mental states (and deviance) are revealed through the corporeal language of gesture and movement, and correlate them with (reenacted) ethnographic photographs and filmic depictions of 'possessed' women in mid-20th century Southern Italy. In each case, the camera is used as an instrument for researching and visualizing 'expressions of the passions', thereby reproducing highly sexualized images of "imaginary afflictions" as expressive correlates of mental states.

Cet article analyse la production de stéréotypes visuels dénommés " maladies imaginaires" (Hufeland 1794), définies comme des désordres qui n'ont aucune origine physique mais qui sont liés et potentiellement traités grâce à l'imagination. A partir de l'exemple très connu de "l'hystérie" comme un cliché paradigmatique dans la photographie médicale du XIX et du XXème siècle, je trouve et j'analyse des iconographies qui sont produites autour de l'assomption que les états mentaux (et les déviances) sont révélés à travers le langage corporel des gestes et des mouvements. Je les mets en corrélation avec des photographies ethnographiques (mises en scène) et des descriptions filmiques de femmes possédées durant le milieu du XXème siècle en Italie du Sud. Dans chaque cas, la caméra est utilisée comme un instrument permettant la recherche et la visualisation des "expressions des passions", reproduisant donc des images extrêmement séxualisées des "maladies imaginaires" expressions correspondant à des états mentaux.

Este artículo analiza la producción de estereotipos visuales de las llamadas "aflicciones imaginarias" (Hufeland 1794), definidas como trastornos que no tienen causa física, sino que son 
provocados por - y potencialmente curados gracias a - la imaginación. Basándome en el conocido ejemplo del "histérico" como tropo paradigmático en la fotografía médica del siglo XIX y principios del XX, detecto y rastreo iconografías basadas en la suposición de que los estados mentales (y la desviación) se revelan a través del lenguaje corpóreo del gesto y del movimiento, y las relaciono con fotografías etnográficas (recreadas) y representaciones fílmicas de mujeres "poseídas" en el sur de Italia a mediados del siglo XX. En cada caso, la cámara se utiliza como instrumento para investigar y visualizar "expresiones de las pasiones", reproduciendo así imágenes altamente sexualizadas de "aflicciones imaginarias" como correlatos expresivos de estados mentales.

\section{INDEX}

Keywords: medical photography, audio-visual ethnography, possession rituals, reenactment, mimesis, performativity, imaginary afflictions

Palabras claves: antropología médica, etnografía audiovisual, rituales de posesión, recreación, mimesis, performatividad, aflicciones imaginarias

Mots-clés: photographie médicale, ethnographie audio-visuelle, rituels de possession, mise en scène, mimesis, performativité, maladies imaginaires

\section{AUTHOR}

\section{MICHAELA SCHÄUBLE}

Department of Social Anthropology, University of Berne (Switzerland)

michaela.schaeuble@anthro.unibe.ch 